\title{
Ancestor-reverence as a Basis for Pan-Africanism and the African Renaissance's Quest to Re-humanise the World: An African Philosophical Engagement
}

\author{
Simphiwe Sesanti ${ }^{1}$ \\ ${ }^{1}$ Institute for African Renaissance Studies, University of South Africa (UNISA), South Africa \\ Correspondence: Simphiwe Sesanti, Institute for African Renaissance Studies, University of South Africa (UNISA), \\ South Africa.
}

Received: November 17, 2016

Accepted: December 9, 2016

Available online: December 23, 2016

doi:10.11114/ijsss.v5i1.2099

URL: http://dx.doi.org/10.11114/ijsss.v5i1.2099

\begin{abstract}
Pan-Africanism is an ideological framework whose emphasis is on unity and liberation of all Africans who were colonised on the African continent, and those in the diaspora who were forcibly dislocated from Africa and dispersed as slaves. The African Renaissance is a pan-Africanist project that seeks to restore to the Africans the spiritual and material values that were dented by colonialists and enslavers. In 1963, a number of African states that had gained independence formed the Organisation of African Unity (OAU) to pursue the goals of pan-Africanism and the African Renaissance. One of the major criticisms against the OAU and its successor, the African (AU), was and continues to be that their pan-Africanism is reduced to an elite project by reducing pan-Africanism to a government-to-government relationship, instead of a people-to-people relationship. This means that ordinary Africans are excluded from being directly engaged in finding solutions to the spiritual, political, economic and social ills that continue to haunt the African continent in their quest to re-humanise themselves following the dehumanising colonialism and slavery. Through a philosophical approach, an argument is made that a serious, critical examination of Ancestor-Reverence will expose its potential to give expression to a highly desired sense of African solidarity, people-to-people pan-Africanism, and a fulfilment of the African Renaissance's quest for re-humanising not only Africans but the human race as a whole.
\end{abstract}

Keywords: African culture, African philosophy, African renaissance, Ancestor-reverence, pan-Africanism

\section{Introduction and Background}

When Europeans and Arabs came to Africa, among the African institutions that were on the receiving end most, were African spiritual belief systems (Amadiume, 1997). Great efforts were made to displace African belief systems and to replace them with Islam and Christianity (ibid). When African and European cultural values collided, African spirituality was called superstition and Africans were called upon to cast away their indigenous clothing, their customs, their beliefs which were all described as being pagan and barbaric (Biko, 2004). As if this was not enough, African children, through the colonial school system were taught to despise their mode of upbringing at home and to question the values and customs of their society (Biko, 2004).

When Europeans arrived in Africa and found Africans communicating with the Supreme Being through the Ancestor Spirits, they immediately concluded that Africans exercised ancestor-worship. This ancestor-worship is so much echoed by detractors of African culture such that some Africans, in "defence" of African culture, have themselves defiantly argued that they worship their Ancestor Spirits (Rukuni, 2007). Yet, a number of African scholars (Rukuni, 2007; Mphahlele, 2002; Ntuli, 1999; Gyekye, 1996; Williams, 1987; Mqhayi, 1981) have clearly stated that traditional Africans revered, not worshipped their ancestors. Refuting the ancestor-worship claim, Gyekye (1996) notes that Africans' intense reverence for their forebears gave $18^{\text {th }}$ century European scholars the impression - albeit false - that Africans worshipped their ancestors, and hence the characterisation of traditional African spirituality as ancestor-worship. It is against this background that wa Thiong'o (2005) argues that wherever European colonialists went in the globe, in their desire to establish and entrench colonialism, they sought to plant their memory. European colonialists did this by naming and renaming the places and cultures they encountered, thus displacing the conquered's memory, and replacing it with the conqueror's. In the case of African spirituality, early European anthropologists felt that the concept of God was too sublime for the African understanding (Wiredu, 2003a). They assumed that Africans 
were not God-conscious, even though nowadays many outside the African cultural communities outdo one another in arguing that Africans are a profoundly religious people (Wiredu, 2003a). Even as Mbiti (1989) points out that many African languages do not have a word for religion, as such, the absence of the word does not equate to a spiritual void among Africans. The absence of such a word makes sense because, historically, for Africans there was no formal distinction between the sacred and the secular, between the religious and non-religious (Mbiti, 1989). With specific reference to ancient Egypt, Hilliard (2003), notes that ancient Egyptians did not distinguish between the church and the state, just as is the case with the rest of traditional Africa. Spirituality to the Africans, traditionally, was far more than rituals reflecting belief, but a reality reflected in their actual life, a dynamic force in the development of all major aspects of African civilisation (Williams, 1987). Despite protestations and explanations, Africans' cultural identity continues to be misinterpreted and misrepresented by others - hence the prevailing reference to Ancestor-Reverence as ancestor-worship.

Here it is argued that Ancestor-Reverence is one area of African life that requires greater conceptual reclamation, otherwise known as the African Renaissance. This is so because perennial distortion has not only disfigured the African image to the rest of the world but blinded Africans' view to the great potential the African philosophy on Ancestor-Reverence could contribute to the re-humanisation not only of Africans but the entire human race if the ethical thrust of Ancestor-Reverence were appreciated. In fact the basis of Ancestor-Reverence is the appreciation of the philosophy (African Humanism - to be discussed later) of the ancestors that emphasised fairness and justice to fellow humans and all creation.

This article contests claims which argue that Ancestor-Reverence is negative from the point of view of the trends, demands, and development of a modern African society, and that, therefore, it will be to Africans' moral, social, political, and intellectual chagrin to argue for its revival or maintenance and continuity (Gyekye, 1997). In rejecting the reclamation of Ancestor-Reverence, Gyekye (1997) argues that Africans pay unnecessarily excessive and incessant attention to their ancestors in the belief that, having gained a spiritual status that presumably is invested with power that human beings do not possess, the ancestors are believed to be in a position to bestow honours on their living descendants. Gyekye (ibid) argues that such beliefs are incapacitating, resulting in those believing in ancestors abandoning agency, and uttering words such as "This is what the ancestors said" or "This is what the ancestors did". While it is true that some Africans employ an excessive approach to Ancestor-Reverence, this is not the case with all Africans who subscribe to this phenomenon. What is needed for Ancestor-Reverence is Kamalu's (1990) recommendation that studies of African spirituality should have a special place in any African educational curriculum in the sense that its philosophy should create an attitude permeating the study of all other subjects. That is because, as Mbiti (1989) argues "a study of traditional religions brings us into those areas of African life where, through word and action, we may be able to discern the philosophy behind [it]" (Mbiti, 1989). In line with Kamalu's and Mbiti's approach, this article interrogates the philosophy (logic) behind Ancestor-Reverence and how it can contribute towards pan-Africanism and the African Renaissance's quest not only to re-humanise Africans but humanity in its entirety. We depart from the premise that though not all Africans subscribe to Ancestor-Reverence, the belief system, expressed in various ways, by many African ethnic groups, exists throughout the African continent. We begin first with tracing some highlights of the OAU and the AU's march in the struggle for the re-humanisation of Africans through pan-Africanism and the African Renaissance. To create an appreciation of the meaning of Ancestor-Reverence, we proceed to interrogate the meaning of "death" in the African cultural context. This is followed by the interrogation of the meaning of Ancestor-Reverence, followed by a critical examination of the meaning of libation, a ritual associated with Ancestor-Reverence. These examinations are followed by an examination of "African Humanism", a philosophy about what constitutes "being human" in African culture. It is African Humanism, the ancestors' gift to Africans which the ancestors are revered for, which Africans must reclaim for the re-humanisation of Africa and the world.

\section{The OAU and the AU's March in the Struggle for Re-humanising Africa through Pan-Africanism and the African Renaissance}

Taking into cognisance Murithi's (2015) observation that there is no single definition of pan-Africanism and that there are as many ideas about pan-Africanism as there are pan-African thinkers, this exercise draws from Matlosa's (2015) definition of pan-Africanism as the ideology of African unity, self-determination and liberation. While there may be many definitions of pan-Africanism, there is no contestation that pan-Africanism was the force that inspired the formation of the Organisation of African Unity (OAU) in 1963, and its successor, the African Union (AU) in 2002, towards the unity and integration of Africa (Matlosa, 2015). While both the establishment of the OAU, and later the AU, was a laudable initiative for Africans, the unpalatable reality is that to a great extent the ordinary African citizens know nothing about the AU, and pan-Africanism for them is not a lived experience (Murithi, 2014). The concern about the AU's inaccessibility to the ordinary African people is an echo of a sentiment articulated about its predecessor, the OAU, moving wa Thiong'o (2005) to urging Africans to look at pan-Africanism as a people-to-people relationship and not a 
monopoly of the African heads of states.

The leadership of the new AU is sensitive to Africans' objection to the gap between them and the AU, thus reducing Africans to spectators. Regarding its Agenda 2063 - a strategic framework for the socio-economic transformation of the continent over the next 50 years - following the OAU's $50^{\text {th }}$ anniversary in 2013, the AU (AU, N.D) emphasises that what distinguishes Agenda 2063 from past continental initiatives is that there were extensive consultations of the African Citizenry. This being the case, the AU (ibid) emphasises that this enhances ownership of both the processes and outcomes of the initiative for having a continental agenda for socio-economic transformation. Agenda 2063, the AU (ibid) stresses, is not a bureaucratic exercise, but rather an Agenda driven by the voices of the African people indicating the Africa they quest for. Driving the point about a people-sensitive AU, one of the seven African Aspirations for 2063, the AU notes, is An Africa whose development is people-driven, relying on the potential offered by people, especially its women and youth and caring for children. The second of the African Aspirations for 2063, relevant for this article, is an integrated continent, politically united, based on the ideals of pan Africanism and the vision of Africa's Renaissance. Being one of its focuses, the AU (nd) emphasises that Agenda 2063 needs to be seen as a part of an African Renaissance which calls for changes in attitudes, mindsets to inculcate the right set of African values, i.e., discipline, focus, honesty, integrity, transparency, hard work and love for Africa and her people. Just as the OAU/AU has been seen as an elite project, the same criticism has been raised regarding the African Renaissance project - discussed next - when it was spearheaded in South Africa by then then country's president, Thabo Mbeki, in the second half of the 1990s.

\section{The African Renaissance: Meaning and Context}

The invocation of the term "renaissance", Mugo (1999) observes, certainly brings back to mind, to those familiar with European history, the European Renaissance which took place between the $14^{\text {th }}$ and $16^{\text {th }}$ centuries. While this occasion in Europe saw the revival of the arts, sciences and education, for Africa and other colonised lands, Mugo (ibid) further points out, this event became a negation of Africans' achievements. That is because the European Renaissance produced the human and technological resources that were later used by the architects of imperialism to enslave and colonise Africans (ibid). Consequently, the African challenge is, therefore, designing an African Renaissance that truly addresses the recovery and renewal of not just her people and their destroyed heritages, but space in which all members of the human race find themselves in celebration of fulfilled lives (ibid).

This vision of the African Renaissance by Mugo, echoes Diop's articulation, in seeing Africa and her people as the hope for humanity (Clarke, 1991). The above reveals that African people's struggles against colonialism, inspired by the ideology of pan-Africanism and a quest for self-reclamation, otherwise known as the African Renaissance, were not only preoccupied with their own freedom, but also that of the whole of humankind. Informed by this view, the first president of the Pan Africanist Congress, one of South Africa's liberation movements, Mangaliso Sobukwe, articulating his pan-Africanist movement's vision, declared that "[w]e are fighting for the noblest cause on earth, the liberation of mankind" (Pogrund, 2015). Later, Biko (2004) would declare that while the great powers of the world may have done wonders in giving the world an industrial and military look, the great gift still has to come to Africa - giving the world a more human face. Biko (ibid) held the view that the Western world was ever concerned with perfecting their technological know-how while losing out on their spiritual dimension. While on one hand Biko (2004) opposed Western values, on the other hand he proposed African culture, arguing that inescapable was the fact that the culture shared by the majority group in any given society must ultimately determine the broad direction taken by the joint culture of that society. While Biko (ibid) conceded that his proposal needed not cramp the style of those who felt differently, on the whole, a country in Africa, in which the majority of the people were African, should inevitably exhibit African values and be truly African in style. This suggestion did not in any way suggest that Africans who had accepted Western cultures, and other people coming from outside Africa would be forced to give up their cultural choice. What Biko meant, and advanced in this exercise, is that African culture must be a central determinant in the political, social and economic life in Africa. However strong these aspirations for African Renaissance have been, implantation has proven elusive.

\section{The African Renaissance: Constraints and Challenges}

Twenty years after Mbeki's overt commitment to the African Renaissance, Adebajo (2016) argues that a grassroots African Renaissance movement appears to be a distant pipe-dream. Earlier, Harvey (1999) had pointed out that absent in the drive for the African Renaissance was a coherent theoretical framework which engaged head on with issues related to imperialism, globalisation, development and economic growth from a grassroots African perspective. Harvey (ibid) was of the firm view that the African Renaissance needed to address the horrible conditions faced by desperate Africans who were harassed by grueling poverty. In Harvey's (ibid) view, major institutions of the world economy, the International Monetary Fund (IMF), World Bank and the World Trade Organisation (WTO), led by the United States, which have tightened their controlling grip over Africa, were not addressed by the leading proponents of the African 
Renaissance. Instead, Harvey further argued, the African Renaissance proponents have tended to subordinate or obscure the deeper causes of the current crisis behind relative abstractions, like calls for cultural renewal, moral rectitude and pride. In Harvey's view,

\section{The only path to restoring the lost dignity and pride of Africa and Africans is through fundamental changes to the material conditions of [the] people. This is only going to happen by drawing the teeming millions, who cannot take their condition any longer, into the mainstream of the renaissance.}

Harvey is quite correct in arguing that the African Renaissance should address concrete problems of the African people instead of being merely abstract. The weakness in his argument, though, is separating culture - which the African Renaissance advances - from issues of hunger and other material needs. Happily, the African Union's (AU, 2006) Charter For African Cultural Renaissance has addressed this issue by observing that

\section{African culture is meaningless unless it plays a full part in the political, economic and social liberation struggle, and in the rehabilitation and unification efforts and that there is no limit to the cultural development of a people.}

The AU (2006) defines culture as a set of distinctive linguistic, spiritual, material, intellectual and emotional features of the society or a social group, and that it encompasses, in addition to art and literature, lifestyles, ways of living together, value systems, traditions and beliefs. Historically, the AU (AU, 2006) correctly recalls, the African peoples were able to find in African culture the necessary strength for resistance and the liberation of the continent. On this basis, it is then reasonable to draw from African culture the inspiration to move forward. That is the meaning of the African Renaissance. Cognisant that African culture has many dimensions, in this exercise the focus in on Ancestor Reverence discussed next - and how it can contribute towards the re-humanisation of Africans and humanity.

\section{Ancestors and Ancestor-reverence: The Meanings}

This section moves from the premise that Ancestor-Reverence is a pan-African spiritual belief. This, however, is not the same as saying that all Africans practise it. Some Africans are Christians, while others follow Islam, Judaism and many other beliefs. But the point that is being made is that Ancestor-Reverence is found throughout the African continent. While other members of the human race may celebrate their ancestors in their own unique ways, the focus here is on Africans. In this section examples will be drawn from a number of different African ethnic groups demonstrating how Ancestor-Reverence is practised and the logic behind the practices.

In African traditional beliefs the ancestors are those who have passed on and said to have distinguished themselves in many ways and, in particular, by performing s/heroic deeds in the service of humankind (Gyekye, 1996). Among the criteria to be met to qualify as an ancestor, Shoko (2012) notes that among the Shona Africans, the deceased must have demonstrated moral rectitude in her/his lifetime. So interpreted, not just any departed member of the lineage qualifies as an ancestor. For the Bê Africans, ancestral values are a source of high moral qualities requiring the observance of virtue at all times, respect for one's word, respect for other people's property and the common wealth, honour and dignity in relations with others, and the exaltation of work (Obenga, 2004). Ancestor-Reverence for the Bê Africans entails urging all who regard themselves as human beings not "to trample on other's rights, to lie knowingly for the purpose of covering up truth or harming others, to be cruel to the weak, to embezzle property under one's stewardship, or to refuse drink to strangers, no matter what their identity or destination" (Obenga, 2004). Believing that earthly life is transient, the Bê feel duty-bound to honour these values because according to Bê tradition, there is a supreme court in the land of the ancestors, where the virtuous are rewarded and the unjust punished (Obenga, 2004). While the notion of a day of judgement may not be universal among Africans, it is certainly true that African culture in general holds that ancestor-spirits reward those who do good, and punish those who commit evil (Shoko, 2012; Wiredu, 2003; Gyekye, 1996; Peires, 1989). This is an important observation because some Africans - in defence of African culture - argue that Africans did not believe in the punishment of human beings in the hereafter for wrongs committed in this life.

Arguing this point, Biko (2004) and Mphahlele (2002) point out that Africans never knew anything about hell, blaming the Christian missionaries for spreading such a belief among Africans. While acknowledging that the majority of African people traditionally did not expect any form of judgment or reward in the hereafter, Mbiti (1989) concedes that Africans have only a few exceptions to this statement, citing the Yoruba who believe that after death the person presents oneself before God and gives an account of his earthly life. Also citing the case of the Lodagaa, Mbiti (1989) points out that these Africans believe that the land of the departed lies to the west, separated by the river of Death. As soon as the funeral rites are performed, the soul begins its journey. Crossing the river, the Lodagaa believe, is an ordeal whose hardness depends on the nature of the life that a person has led on earth (ibid). The Lodaaga believe that good people get across easily, but "bad" people fall through the boat and must swim across the river, which can take up to three years to do so. 
Mbiti also cites the Ga Africans who also believe that at death the soul must cross a river, and on arrival at the other side, the nose is broken so that the departed speak in nasal tones. It is not only among the Lodagaa Africans and the Ga Africans that this belief about crossing the river is found. A similar phenomenon is found among the ancient Egyptians. Diop (1991) observes that two thousand years before Moses, and three thousand years before Christ, if a deceased person during her/his terrestrial life had satisfied the different moral criteria, s/he gained a garden protected by an iron wall with several gates, and a river running through it. Hell, Diop (ibid) further notes, is reserved for punishment of the impious.

Except for the cases mentioned above, as Mbiti (1989) notes, there no evidence of the hereafter being pictured in terms of punishment or reward. Where there is no disagreement, though, is that Africans believed that ancestors rewarded and punished, whether in this life or in the hereafter. What is not contested, as Mbiti further points out, is that for the majority of African peoples, the hereafter is only a continuation of life more or less as it is in its human form (Mbiti, 1989).This being the case, African culture teaches that if the ancestors are forgotten, this means that they are cast out, effectively excommunicated, their personal immortality destroyed and their being turned into a state of non-existence, something regarded as the worst possible punishment, and something that the ancestors resent (Mbiti, 1989). Africans who subscribe to Ancestor-Reverence avoid this because it is feared that it would bring illness and misfortunes to those who forget their departed relatives (ibid). This discussion tells us something about African cultural beliefs about death, a point discussed next.

\section{Death: An African Cultural Context}

Generally, death among Africans is seen as a departure from the physical to the spiritual world (Mbiti, 1989). Echoing this, Peires (1989) observes that

[f]or the [...] African peoples, death was not a definite and conclusive departure from the earth. The dead lived on, though in a somewhat altered state.

Among the Nandi Africans a custom of laughing was practised when a very old person was buried, celebrating her/his arrival at an anticipated destination (Mudimbe, 1994). Mudimbe goes on to note that the practice of laughing at funerals has always been widespread in eastern and central parts of the continent. This being at peace with the inevitability of death finds expression among the funeral songs of the Bê Africans:

Our home is the abode of the dead. Fresh happiness awaits those who lived in serene patience (Obenga, 2004).

This approach among the Bê Africans is an expression of yearning for eternity, and by interpreting death as a transition to a better and more dignified life is also to bar the way to despair (Obenga, 2004). This type of engagement with death is not only philosophical but also psychological. This African attitude to death has misled some to assume, as Russel (2004) does with particular reference to the ancient Egyptians, that the Egyptians were preoccupied with death. To the contrary, Egyptians had an obsession with eternal life (Fletcher, 2015). As Carruthers (1984) notes, it must be emphasised that ancient Egyptians were neither obsessed nor preoccupied with death. To the contrary, they enjoyed life and were quite realistic about death (ibid). With this realisation all or most of what they did was with the future destination in mind. Keeping death in mind at all times was/is a reminder to prepare for the ultimate - a departure to the abode of the ancestors.

One of the ways of remembering the ancestors is through the exercise of libation, discussed below.

\section{Libation: Deeper Meaning beyond the Rituals}

Libation is the symbolic act of giving of food and drinks to the ancestors as tokens of fellowship, hospitality and respect, these being offered as symbols of family continuity and contact (Mbiti, 1989). Placing portions of food and drink for the departed is an expression about the necessity and value of the ancestors' spiritual presence, a statement which can be made materially because of the relationship between spirit and matter (Richards, 1990). The offerings to the ancestors symbolise reciprocity in the belief that as earthly dwellers receive from the spiritual world, the former must reciprocate (Richards, 1990). Honouring the ancestors is not a one-way but a two-way process because the belief is that as the ancestral world keeps the earthly world strong, the latter must do their part in keeping the former strong - just as humans need their ancestors, the ancestors need humans, too (Richards, 1990). If Kunene (1982), testifies to the impressive totality of the ancestors' achievements, but in the same vein argues that for the sake of progress even such achievements are open to critical evaluation, since by their very nature they pose a challenge to the present generation to achieve as much and excel, it is appropriate to raise some issues regarding claims on one hand, and practice, on the other hand, regarding libation, discussed next

\section{Libation: A Critique}

Nehusi (2016) points out that preparations for libation entail ensuring that the libationer is of correct spiritual 
disposition and in a correct state of mind (my emphasis). While performing libation using milk, honey, water, tea and coffee, listed by Nehusi (2016) as drinkable liquids that can be used for performing libation, which, surely, will not interfere with the correct state of mind, how does the use of liquor, including rum, gin, beer and wine, listed by Nehusi (ibid), which certainly interferes with the correct state of mind (my emphasis), reconcile with the quest to be in $a$ correct state of mind (my emphasis)? This question is especially pertinent, taking into cognisance that rum and gin are intoxicating liquids of European origin.

In 1854, Moshoeshoe, the BaSotho Africans' king, reputed as one of the wisest African kings to have lived, banned the use of European liquour in his kingdom (Mokhehle, 1990). Moshoeshoe regarded the matter so seriously such that he warned that if "any person, whether white or black contravenes this order, the spirits shall be taken from him and poured on the ground, without excuse and indemnification" (ibid). Moshoeshoe held a strong view that a good Chief and Judge could not claim to be competent to execute his duties, if he made use of anything of an intoxicating nature, and further declared that spirituous liquors created quarrelling and strife, and paved the way to the destruction of society. With specific reference to European liquor which he banned in Lesotho, Moshoeshoe declared that "for surely the spirituous liquors of the whites are nothing else than fire" (ibid). Moshoeshoe's position towards liquor had been influenced by his mentor, Mohlomi, who did not spare from criticism Africans' own brand of liquor. So, the issue was not about the geographical origin of beer - African or European - but about its destructive effect on human beings. Equally true, though, is that Moshoeshoe believed that European liquor was stronger than African beer (ibid). Mohlomi (Mokhehle, 1990) observed that in his lifetime he had seen chiefs who were once strong, virile young men becoming addled, weak-limbed, constantly plagued by hallucinations, and succumbing to the destructive influence of sorghum beer. Mohlomi's and Moshoeshoe's logic is compelling, and advocates of the African Renaissance would do well to take their counsel against liquor, especially where rituals aimed at Africans' spiritual development, such as libation, are concerned.

If the precondition of becoming an ancestor entailed performing acts of virtue, it goes without saying that such performance had to take place this side of life before crossing to the other side of life. Such a supposition compels us to interrogate the meaning of being human before becoming an ancestor. Such an interrogation leads us to the examination of the pan-African philosophy known as African Humanism, discussed next.

\section{African Humanism - The Ancestors' Philosophy}

Discussing African Humanism, also known as Ubuntu, Botho, Unhu in some African languages, Rukuni (2007) observes, African Humanism is not only the way of life that the ancestors crafted, but also believed to be the entry point and end point of all the various pathways leading to the Supreme Being. Gyekye (1997) observes that if one were to look for a pervasive and fundamental concept in African socioethical thought generally - a concept that animates other intellectual activities and forms of behaviour, including religious behaviour, and, and provides continuity, resilience, nourishment, and meaning to life - that concept would be humanism. Gyekye (ibid) defines humanism as a philosophy that sees human needs, interests, and dignity as of fundamental importance and concern. What is significant in Gyekye's definition is that he underlines the fact that African Humanism philosophy pervades every action, including religious behaviour. This means that African philosophy is not merely abstract but practical.

In Yoruba, the word for person is eniyan (Gbadegesin, 2003). To the Yoruba, the normative meaning of eniyan is to contribute to the totality of the good in the universe (Gbadegesin, 2003). To the Yoruba, therefore, the crown of personal life is to be useful to one's community, the meaning of one's life being measured by one's commitment to social ideals and communal existence (ibid). Among the Akan of Ghana the word onipa, which in English translates as "person in the sense of human being", has an ordinary meaning and a normative conception (Wiredu, 2003b). In the ordinary sense everyone is born a person. However, in the normative sense, personhood implies the recognition that $\mathrm{s} / \mathrm{he}$ has attained a certain status in the community (ibid). Specifically, Wiredu further points out that this implies that the person has demonstrated an ability through hard work and sober thinking to sustain a household and make contribution to the communal welfare (ibid). In this sense, therefore, personhood is not something you a person is born with, but something to be achieved, subject to degrees, depending on the degree of fulfilment of one's obligations, to self, household, and community (ibid). Menkiti (2006) makes sense when observing that from an African philosophical perspective, reaching personhood or being human is a journey. Echoing Wiredu's observation that personhood is the sort of thing which has to be achieved, Menkiti (ibid) simultaneously cautions that it is the sort of thing at which individuals could fail. Recognising the potential of failure to achieve personhood, of necessity, this requires the intervention of the community in which individuals reside. Menkiti (ibid) observes in this regard that the community always plays a vital role both as catalyst and a prescriber of norms. Members of the community join the task of transforming the individual into a true person, in other words, a moral being or bearer of norms (ibid). The reasoning behind this is that in order to transform what was initially biologically given into full personhood, the community has to intervene, since they cannot carry through the transformation unassisted (ibid). 
As Callinicos (1996) notes, “[a] person's worth in African society was measured in terms of his or her contribution to the community as a whole". This means that for Africans, to be human is to be morally, socially and spiritually engaged with your fellows in the enterprise of human living, and if one is disengaged s/he become less human (Khoza, 2011). Informed by this understanding, Mphahlele (2013) correctly points out that the basis of the African's traditional religion lies in the realm of social relationships, in action among other people, in the continued contact between human beings and the external nature through the spirits of the ancestors. Critical to note in Mphahlele's observation is that African traditional religion does not only advance the notion of appreciation of, and respect for human beings only, but for also for nature as well, animate and inanimate. This is the case because African wisdom teaches that all created beings are intelligent and therefore sacred (Rukuni, 2007). This being the case, therefore, all of creation needs to be regarded with utmost respect, nature being part of human beings and human beings being part of creation (ibid). Taking this into cognisance, Rukuni (2007) points out that despite human beings' terrible capacity for violence, humans should care for all of creation, because the ancestors taught that human beings should always live in harmony with animals and plants. When a person falls below these expectations, the Yoruba to refer to her/him as Ki i se eniyan, (Gbadegesin (2003), the baSotho as ha se motho (Khoza, 2011) and amaZulu as asingomuntu lowo (Dandala, 1996) - all these meaning that such a person is not a human being.

Driven by African Humanism philosophy, as Mutwa (1996) observes, it is not an exaggeration to say that African people had more laws governing people's behaviour towards the Earth, plants and animals than they had governing other acts of human behaviour. To that effect during the planting season, traditional Africans conducted rituals not only with the aim of ensuring a good harvest, but to also thank the Earth Mother and to apologise for injuring her sacred flesh in order to plant food (ibid). During the hunting seasons traditional Africans would prepared by talking to the ancestors, and to the Great Creator, and when they reached the forest, they would speak also to the local spirits and ancestors looking after the forest on the Creator's behalf, to ask for permission to hunt, in order to feed their families (Rukuni, 2007).The hunt being always governed by very strict rules and taboos, elders in the community kept a close watch on all the hunters to make sure that no-one brought down more animals than was necessary for meat and for skins (Mutwa, 1996). That was so because traditional Africans believed that a plant should be uprooted, and an animal killed only for a worthy purpose (Rukuni, 2007).

In Kenya, before the Europeans' arrival, Mount Kenya was called Kirinyaga, meaning "Place of Brightness" (Maathai, 2009). The Kikuyus held the belief that the Supreme Being dwelled on the mountain and that rains, clean drinking water and crops flowed from Kirinyaga. But when Christian missionaries arrived in the area, they dismissed this belief, telling the people that the Supreme Being did not dwell on Kirinyaga but in heaven, and that the mountain and its forests previously considered sacred grounds, could be encroached upon and the reverence accorded to them abandoned (Maathai, 2009). The inhabitants accepted the European Christian logic and were persuaded to consider their relationship with the mountain and, indeed, nature itself as primitive, worthless, and an obstacle to development and progress in an age of modernity and advances in science and technology (ibid). This attitude of elevating technology and relegating nature welfare is contrary to the spirit of the philosophy of African Humanism. As Wiredu (1980) notes it is of little profit for human beings to gain all the technology in the world and lose the humanist essence of our culture. A careful examination of those societies in which technology has been developed to a high degree and in which, consequently, the very form of life has been transformed by industrialisation, would reveal there is a tendency for the qualities of spontaneity and fellow feeling to be eclipsed (ibid). This happens because, Wiredu (1980) further argues, an industrialism further propelled by large machines and motivated by a single-minded calculation of profitability whether to private industrialists and businessmen, as in capitalism, or to the state, as in socialism, tends to create large towns and cities in which people live for the most part as strangers, with relationships regulated by the formal rules of state law rather than the informal rules of face-to-face communal living. Thus social life thus becomes more formal, sympathies more restricted, and, amidst the gradual withering away of the tradition of communal caring, many individuals begin to lose their sense of human security (ibid). This criticism is not the same as saying that technological advancement is undesirable. Rather, as Wiredu (1980) points out, it is not technology or industrialisation in itself that is responsible for the undesirable developments, but, rather, the unrestrained urbanisation which accompanies a narrowly oriented industrialism.

Observing that humankind seems to seek technical developments for the sole purpose of exploiting the environment for personal gains in wealth and power, Hilliard (2003) reminds us that while ancient Egyptians achieved high level technical developments, what was important was not so much the level of technical development as the philosophical orientation of the users of the technology. The ancient Egyptians' philosophical orientation, was that technology should assist to develop a greater understanding of humankind's relationship to nature and humankind's place in nature (ibid). It is the reclamation of this African philosophical approach to technology that this article calls for. Mphahlele (2013) in calling for the reclamation of African Humanism argues that Africans can still find their way to the ancestors who are a vital part of their humanism, further pointing out that this is a state of mind, which is why it can work in urban areas as well as in those rural 
areas where the traditional institutions no longer exist. When the way to the ancestors has been rediscovered, African Humanism should continue to absorb and redefine the technological, economic and political systems, which Africans must master if they are to participate effectively in international business and politics (Mphahlele, 2013). Even though African culture has had to sustain severe blows and may have been battered nearly out of shape by the belligerent cultures it collided with, Biko (2004) notes that in essence fundamental aspects of the pure African culture can still be found in the present day African. It is the remnants of African culture that Biko sought to reclaim for a post-colonial South Africa. Biko (2004) held a strong view that from African indigenous cultures a lot of positive values could be extracted which could teach the Westerner a lesson or two, one of them being that the oneness of community for instance is at the heart of African culture.

\section{Conclusion}

In this exercise the quest was to advance the idea that in order for Africans to accomplish their task of African unity, expressed through the ideology of pan-Africanism, and to reclaim Africans' cultural freedom, political, social and economic independence, expressed through the African Renaissance project, Africans must rediscover their traditional spirituality expressed through Ancestor-Reverence. In making this call, the objective was not seeking conversion or reconversion of those pursuing other faiths. Rather, the argument's main thrust is that those Africans who subscribe to Ancestor-Reverence must go beyond the surface in appreciating and practicing Ancestor-Reverence. In doing so, they are called upon to interrogate the philosophical underpinnings of this phenomenon. If and when this is done, a consciousness will emerge which would point Africans in the direction of African Humanism, known by various names in indigenous African languages. Such an interrogation will reveal that despite the existence of many cultural variations among Africans, there exists an underlying African cultural unity, particularly revealed through the philosophy of African Humanism. This consciousness will give Africans a clear basis for both pan-Africanism and the African Renaissance. That is so because Africans will appreciate the cultural ties that bind them. Once this has been established, it will show that there is something common to reclaim, something unifying to be reborn.

Of great significance in all this exercise is that the unity to emerge is not to be confined amongst the elite. This re-birth of consciousness, this reclamation of African cultural values, will bring forth a re-awakening amongst the ordinary masses the African people. It will restore to them a sense of self-esteem and agency. That is because even with centuries of colonialism, with all the constraints that they experienced, African Humanism, known in various African languages was never obliterated.

But this philosophical exercise calling for reclamation of African cultural values is not an exercise in acclamation. Philosophy is a critical exercise that emphasises logic. Therefore, while appreciating the beauty and the logic in libation, a call for caveat has been raised. While anyone and everyone has a right to choose to consume or not consume alcohol, an objection has been raised with reference to centering its use in the sacred practices that seek to honour African heritage. This objection is not whimsical but located in a historical context, that of the baSotho sages, King Moshoeshoe who saw European liquor as extremely strong, and banned it in the baSotho kingdom, and Mohlomi, who was Moshoeshoe's mentor, who did not spare African been either, and condemned it for its mental and physical weakening effect on the baSotho men. If African rituals in the honour of the ancestors are meant to strengthen the African people in all respects, then liquor, whether African or European, cannot and should not be at the centre of Ancestor-Reverence rituals.

It is in a state of soberness - not otherwise, that African men and women can lucidly and clearly explain to their young ones the logic in Ancestor-Reverence, so that the young ones will be the ones who will appreciate the importance of advancing and elevating African Humanism, the ancestors' philosophy for the liberation of not only Africans but for humanity as well - a quest for pan-Africanism and the African Renaissance.

\section{References}

Adebajo, A. (2016). Thabo Mbeki: A Jacana Pocket Biography. Auckland Park: Jacana.

African Union. (2006). Charter for African Cultural Renaissance.

African Union. (N.D). About Agenda 2063. http://www.au.int/en/agenda2063/about. Accessed 2016/11/02.

African Union. (N.D.). About Agenda 2063. http://agenda2063.au.int/en/print/1007. Accessed 2016/11/02.

Amadiume, I. (1997). Reinventing Africa: Matriarchy, Religion \& Culture. London \& New York: Zed Books Ltd.

Biko, S. (2004). I Write What I Like. Johannesburg: Picador Africa.

Callinicos, L. (1996). The multiple worlds of South Africa's historiography. In Lessem, R. \& Nussabaum, B. (eds), Sawubona Africa: Embracing four worlds in South African management. Sandton: Zebra Press, 92-116.

Carruthers, J. H. (1984). Essays in Ancient Egyptian Studies. Los Angeles: University of Sankore Press. 
Clarke, J. H. (1991). Foreword. In Diop, C.A. Civilization Or Barbarism: An Authentic Anthropology. New York: Lawrence Hill Books. https://doi.org/10.4159/harvard.9780674429802.prf

Dandala, H. M. (1996). Cows never die: Embracing African cosmology in the process of economic growth. In Lessem, R. \& Nussabaum, B. (eds), Sawubona Africa: Embracing four worlds in South African management. Sandton: Zebra Press, 69-84.

Diop, C. A. (1991). Civilization Or Barbarism: An Authentic Anthropology. New York: Lawrence Hill Books.

Fletcher, J. (2015). The Story of Egypt. London: Hodder.

Gbadegesin, S. (2003). Eniyan: The Yoruba concept of a person. In Coetzee, P.H. and Roux, A.P.J. (eds), The African Philosophy Reader. Second Edition. Cape Town: Oxford University Press of Southern Africa, 175-191.

Gyekye, K. (1996). African Cultural Values: An Introduction. Philadelphia and Accra: Sankofa Publishing Company.

Gyekye, K. (1997). Tradition and Modernity: Philosophical Reflections on The African Experience. New York and Oxford: Oxford University Press. https://doi.org/10.1093/acprof:oso/9780195112252.001.0001

Harvey, E. (1999). Can the renaissance turn Africa around? Mail \& Guardian, November 12-18, 30.

Hilliard, A. (2003). Pedagogy in Ancient Kemet. In Mazama, A (Ed), The Afrocentric Paradigm. Trenton and Asmara: Africa World Press, Inc., 265-293.

Kamalu, C. (1990). Foundations Of African Thought. London: Karnak House.

Khoza, R. J. (2011). Attuned Leadership: African Humanism as Compass. Johannesburg.

Kunene, M. (1982). The Ancestors \& the Sacred Mountain. London: Heinemann.

Maathai, W. (2009). The Challenge for Africa: A New Vision. London: William Heinemann.

Matlosa, K. (2015). Pan-Africanism, the APRM and the ACDEG: What Lies Ahead? In Grudz, S. and Turianskyi, Y. (Eds), African Accountability: What Works and What Doesn't. Johannesburg: South African Institute of International Affairs, 8-38.

Mbiti, J. S. (1989). African Religions and Philosophy. Second Edition. Johannesburg: Heinemann.

Menkiti, I. A. (2006). On the Normative Conception of a Person. In Wiredu, K. (ed). A Companion to African Philosophy. Oxford: Blackwell Publishing Ltd., 324-331.

Mokhehle, N. (Ed). (1990). Moshoeshoe I: Se-Moshoeshoe. Maseru: Mmoho Publications.

Mphahlele, E. (2002). Es 'kia. Cape Town and Johannesburg: Kwela Books and Stainbank \& Associates.

Mphahlele, E. (2013). Afrika My Music. Cape Town: Kwela Books.

Mqhayi, S. E. K. (1981). Ityala Lamawele. Alice: Lovedale Press.

Mudimbe, V. Y. (1994). The Idea of Africa. Oxford: James Currey.

Mugo, M. G. (1999). African Culture in Education for Sustainable Development. In Makgoba, M.W. (Ed), African Renaissance: The New Struggle. Sandton and Cape Town: Mafube and Tafelberg, 210-232.

Murithi, T. (2015). Reflections On Agenda 2063 And The AU As A Norm Entrepreneur. In Grudz, S. and Turianskyi, Y. (Eds), African Accountability: What Works And What Doesn't. Johannesburg: South African Institute of International Affairs, 51-70.

Mutwa, C. (1996). Isilwane - The Animal: Tales and Fables Of Africa. Cape Town: Struik Publishers.

Nehusi, K. S. K. (2016). Libation: An Afrikan Ritual of Heritage in the Circle of Life. Lanham: University Press of America.

Ntuli, P. P. (1999).The Missing Link between Culture and Education: Are we still chasing gods that are not our own? In Makgoba, W. M. (ed), African Renaissance: The New Struggle. Sandton and Cape Town: Mafube and Tafelberg, 184-199.

Obenga, T. (2004). African Philosophy - The Pharaonic Period: 2780 - 330 BC. Popenguine: PER ANKH.

Peires, J. B. (1989). The Dead Will Arise: Nongqawuse And The Great Xhosa Cattle-Killing Movement Of 1856-7. Johannesburg, Bloomington and Indianapolis and London: Ravan Press, Indiana University Press and James Currey. Penguin Books.

Pogrund, B. (2015). Robert Sobukwe: How Can Man Die Better. Johannesburg and Cape Town: Jonathan Ball Publishers. Richards, D. (1990). The Implications Of African-American Spirituality. In Asante, M.K. and Asante, K.W. (Eds), 
African Culture: The Rhythms of Unity. Trenton, NJ: Africa World Press, Inc., 13-38.

Rukuni, M. (2007). Being Afrikan. Johannesburg: Penguin Books.

Russell, B. (2004). History of Western Philosophy. London and New York: Routledge.

Shoko, T. (2012). Teaching African Traditional Religion at the University of Zimbabwe. In Adogame, A., Chitando, E., Bateye, B. (eds), African Traditions In The Study Of Religion In Africa. England: Ashgate, 53-65.

Wa Thiong'o, N. (2005). Europhone or African memory: the challenge of the pan-Africanist intellectual in the era of globalization. In Mkandawire, T. (ed), African Intellectuals: Rethinking Politics, Language, Gender and Development. Pretoria: Unisa., 155-164.

Williams, C. (1987). The Destruction of Black Civilization: Great Issues Of A Race - From 4 500 B.C. To 2000 A.D. Chicago: Third World Press.

Wiredu, K. (1980). Philosophy and an African Culture. London. Cambridge University Press.

Wiredu, K. (2003a). On decolonizing African religions. In Coetzee, P.H. and Roux, A.P.J. (Eds). The African Philosophy Reader. Second Edition. New York: Routledge, 20-34.

Wiredu, K. (2003b). An Akan perspective on human rights. In Coetzee, P.H. and Roux, A.P.J. (eds), The African Philosophy Reader. Second Edition. Cape Town: Oxford University Press of Southern Africa, 313-323.

\section{Copyrights}

Copyright for this article is retained by the author(s), with first publication rights granted to the journal.

This is an open-access article distributed under the terms and conditions of the Creative Commons Attribution license which permits unrestricted use, distribution, and reproduction in any medium, provided the original work is properly cited. 